\title{
CASAMENTO INFANTIL: O DIVÓRCIO DA INOCÊNCIA
}

\section{CHILD MARRIAGE: THE DIVORCE OF INNOCENCE}

\begin{abstract}
FERNANDO ANTÔNIO GERÔNIMO MASSAD Graduando em Direito, modalidade Integral, pela Escola Superior Dom Helder Câmara. Belo Horizonte - MG. E-mail: fernandomassad1@gmail.com.
\end{abstract}

\section{CAIO AUGUSTO SOUZA LARA}

Mestre e Doutor em Direito pela Faculdade de Direito da Universidade Federal de Minas Gerais - UFMG. Professor da Escola Superior Dom Helder Câmara. Pesquisador Associado ao Programa RECAJ-UFMG - Acesso à Justiça e Solução de Conflitos. Secretário de Comunicação do Conselho Nacional de Pesquisa e Pósgraduação em Direito - CONPEDI. Belo Horizonte - MG. E-mail: caiolarabh@yahoo.com.br.

\section{RESUMO}

O tema-problema da pesquisa que se pretende desenvolver são os efeitos danosos do casamento infantil para as vítimas e para a sociedade brasileira. $O$ trabalho trata da questão do casamento precoce sob o viés das vítimas do gênero feminino. Apesar de haver casos com meninos, menores de idade, e esses casos também serem de extrema relevância, imputa-se dar luz às vítimas mulheres, que são quem protagonizam as maiores estatísticas a esse respeito. Destarte, toda a reconstrução histórica e elucidação social e jurídica serão voltadas à perspectiva supracitada, constituindo o objeto desta pesquisa. O termo "casamento infantil", ou 


\section{Personalidade Acadêmica Homenageada:}

Augustus B. Cochran III (Agnes Scott College)

"casamento precoce" é definido como a união matrimonial formal ou informal na qual um ou ambos os membros possuem menos de 18 anos de idade. O quadro cultural reforça toda uma mentalidade não somente das meninas, mas dos membros da sociedade como um todo, de que as mulheres são feitas para encontrarem um amor que lhes promova sustento e as torne completas, e o quanto antes isso acontecer, mais favorável será. A imposição cultural é tão profunda a ponto de esses valores serem incorporados no indivíduo, não restando outra maneira de ser feliz senão alcançando esses padrões. Não obstante este pensamento tenha diminuído nos últimos tempos com a ascensão de ideais revolucionários e libertadores, eles ainda não são suficientes. Entre a grande massa da população mundial, incluindo a brasileira, este raciocínio arcaico permanece. A título de exemplificação, dados do Fundo das Nações Unidas para a Infância (Unicef) informam que 15 milhões de meninas se casam todos os anos antes de completarem a maioridade, algumas delas pouco depois do décimo ano de vida. Nestes casos, a fria e trágica realidade é clara: a família vê o casamento como o fim da responsabilidade sobre a garota. A partir daí os problemas realmente começam: o favor que o homem fez à família compensa todo tipo de sofrimento, abuso, abandono afetivo, maus tratos e desrespeito à dignidade da vida dela. O problema objeto da investigação científica proposta é: quais são as implicações jurídicas e sociais do casamento infantil no contexto brasileiro? Mediante o breve conhecimento adquirido por meio de pesquisas preliminares, apontam-se impasses de extrema relevância não somente na vida das vítimas, meninas em maior número, mas do corpo social como um todo: evasão escolar, gravidez precoce, violência doméstica, estupro marital, violação de direitos fundamentais de crianças e adolescentes e a perpetuação da pobreza, ou seja, fatos sociais anacrônicos ao ordenamento Jurídico brasileiro. O objetivo geral do trabalho é analisar a ocorrência de casamentos precoces na sociedade brasileira e os obstáculos a eles correlacionados. A pesquisa que se propõe pertence à vertente metodológica jurídicosociológica. No tocante ao tipo de investigação, foi escolhido, na classificação de 
Personalidade Acadêmica Homenageada:

Augustus B. Cochran III (Agnes Scott College)

Witker (1985) e Gustin (2010), o tipo jurídico-projetivo. O raciocínio desenvolvido na pesquisa será predominantemente dialético. De acordo com a técnica de análise de conteúdo, afirma-se que se trata de uma pesquisa teórica, o que será possível a partir da análise de conteúdo dos textos doutrinários, normas e demais dados colhidos na pesquisa. A partir do exposto, conclui-se que a prática deve continuar sendo inaceitável normativamente em vista da gravidade causada pelo problema. Constitui uma permanente violação aos Direitos Humanos a abordagem da evasão escolar, da gravidez precoce, da invasão à sexualidade das jovens e da perpetuação da pobreza, entre as outras diversas transgressões associadas. Enquanto a estrutura da sociedade brasileira corroborar para que esses atentados continuem a ocorrer, o país permanecerá em retrocesso.

PALAVRAS-CHAVE: Casamento infantil; Direito de Família; infância e adolescência.

\section{REFERÊNCIAS}

AGUDO, Alejandra. A união de meninas e a lei, a solução para para acabar com o casamento infantil. EI País. 09 out. 2017. Disponível em: https://brasil.elpais.com/brasil/2017/10/06/internacional/1507297672_697301.html. Acesso em: 08 maio 2019.

BRASIL. Decreto N ${ }^{\circ}$ 99.710, de 21 de novembro de 1990. Convenção sobre os Direitos da Criança. Disponível em: http://www.planalto.gov.br/ccivil_03/decreto/1990-1994/d99710.htm. Acesso em 26 abr. 2019.

BRASIL. Lei no 8.069, de 13 de julho de 1990. Dispõe sobre o Estatuto da Criança e do Adolescente e dá outras providências. Diário Oficial [da] República Federativa do Brasil, Brasília, DF, 16 jul. 1990. Disponível em: http://www.planalto.gov.br/ccivil_03/LEIS/L8069.htm. Acesso em: 29 abr. 2019.

GUSTIN, Miracy Barbosa de Sousa; DIAS, Maria Tereza Fonseca. (Re)pensando a pesquisa jurídica: teoria e prática. 3ª . ed. Belo Horizonte: Del Rey, 2010. 
Personalidade Acadêmica Homenageada:

Augustus B. Cochran III (Agnes Scott College)

POSSA, Ana Lethea da Cunha. A eficácia jurídica da Declaração Universal dos Direitos Humanos. Revista Jurídica - UNICURITIBA, Curitiba, v.20, n. 4, p. 27 - 48, $2007 . \quad$ Disponível em: http://revista.unicuritiba.edu.br/index.php/RevJur/article/view/128/101. Acesso em: 20 maio 2019.

SCHREIBER, Mariana. 'Sinto saudade de ser criança': em uma década, gravidez de meninas de 10 a 14 anos não diminui no Brasil. BBC Brasil. 24 ago. 2017. Disponível em: https://www.bbc.com/portuguese/brasil-40969456. Acesso em 27 abr. 2019.

TAYLOR, A.Y., et al. "Ela vai no meu barco." Casamento na infância e adolescência no Brasil. Resultados de Pesquisa de Método Misto. Rio de Janeiro e Washington DC: Instituto Promundo \& Promundo-US. Setembro 2015.

WELLE, Deutsche. Casamento infantil atinge 20 mil meninas por dia. G1.Globo. 24 out. 2017. Disponível em: https://g1.globo.com/mundo/noticia/casamento-infantilatinge-20-mil-meninas-por-dia.ghtml. Acesso em: 04 maio 2019.

WITKER, Jorge. Como elaborar una tesis en derecho: pautas metodológicas y técnicas para el estudiante o investigador del derecho. Madrid: Civitas, 1985. 